\title{
Legal Implications and Result of Agricultural Soil Function for Settlement
}

\author{
Suryadi $^{1}$ Made Warka ${ }^{2}$ Endang Prasetyawati ${ }^{3}$ \\ Law Doctoral Program, Faculty of Law, Universitas 17 Agustus 1945 Surabaya
}

\begin{abstract}
This article titled "The impact of the conversion of agricultural land for settlements" with the enactment of several laws and regulations in order to protect agricultural land will create confusion regarding the enactment of the law. The purpose of this paper is to analyze the existence of norm conflicts with the enactment of Law No. 41 of 2009 concerning Sustainable Agricultural Land, Law Number 1 Year 2011 concerning Housing and Settlement Areas, and Law Number 19 of 2013 concerning Farmer Protection. The second is analyzing the impacts that occur due to the conversion of agricultural land to housing. Various problems relating to land always arise one after another, especially if it is associated with rapid population growth. Conflict of interest often occurs in practice, that a location that is equally attractive to various development actors. It becomes very crucial if, land issues are linked to the implementation of housing and settlements. Housing development is intended so that every family occupies a decent home in a healthy, safe, harmonious and orderly environment. Housing construction requires legislation that is the legal basis. Housing construction by anyone must follow the provisions of the legislation, so as not to cause problems, disputes and losses. Law Number 1 Year 2011 is a law governing Housing and Settlement Areas. This type of research uses normative research, namely legal research which focuses on the study of legislation that includes a layer of legal science consisting of dogmatic studies of law, legal theory, and legal philosophy. The conclusion of this paper is that with the enactment of several laws and regulations in the context of protection of agricultural land from land conversion, it has turned out to cause legal confusion, so universal legislation is needed. Besides that the conversion of agricultural land to settlements has caused various impacts.
\end{abstract}

Keywords: impact, transfer of function, agriculture, settlement

DOI: $10.7176 / \mathrm{JLPG} / 85-19$

Publication date:May $31^{\text {st }} 2019$

\section{Introduction}

The need for clothing, food and shelter is a very basic human need. Therefore, in order to fulfill these needs for the sake of certainty and legal justice, a rule is needed so that there will be no conflict in meeting needs. Fulfillment of the need for food and the second board is a problem that concerns the land.

As stipulated in Paragraph IV of the Opening of the 1945 Constitution of the Republic of Indonesia, the purpose of the establishment of the Republic of Indonesia is to protect the entire Indonesian nation and all of Indonesia's bloodshed, promote public welfare, educate the nation's life, and participate in implementing world order based on independence eternal peace and social justice.

Housing is a basic necessity in addition to food and clothing, because it is to meet the demand for housing increases with population growth required careful handling with money and power in society

Housing is a basic human need and has a very strategic role in the formation of national character and personality, needs to be fostered and developed for the continuity and improvement of human life and livelihood. Housing is not only a means of fulfilling basic human needs, but more than that it can be a place in the formation of character and personality for humans and the improvement of human life and livelihood.

Housing development requires legislation that is the legal basis, policy, direction, and guidance in the implementation of housing development and the resolution of problems, cases and disputes in the housing sector. Housing construction by anyone must follow the provisions stipulated by legislation, so as not to cause problems, disputes and losses.

Relating to land use, namely agriculture, that agricultural development needs to be supported by spatial planning and land use so that the use, control, ownership and transfer of land rights can guarantee the ease and smoothness of agricultural business and are truly in accordance with the principles of fairness and equity. In line with the provisions governing land stewardship, in the future a basic foundation for land stewardship is needed so as not to cause conflicts of interest within it.

The existence of Law Number 41 of 2009 concerning Sustainable Agricultural Land, Law Number 1 Year 2011 concerning Housing and Settlement Areas, and Law Number 19 of 2013 concerning Protection and Empowerment of Farmers. It is in the context of regulating the construction of housing and settlements, and

\footnotetext{
${ }^{1}$ Student of Law Doctoral Program, Faculty of Law, Universitas 17 Agustus 1945 Surabaya.

2 Lecturer of Law Doctoral Program, Faculty of Law, Universitas 17 Agustus 1945 Surabaya.

${ }^{3}$ Lecturer of Law Doctoral Program, Faculty of Law, Universitas 17 Agustus 1945 Surabaya.
} 
protecting farmers and their agricultural land from the threat of the rate of narrowing agricultural land due to land conversion.

However, if some of the laws are Law Number 41 of 2009 concerning Sustainable Agricultural Land, Law Number 1 of 2011 concerning Housing and Settlement Areas, and Law Number 19 of 2013 concerning Farmer Protection and Empowerment are met, then there will be a norm conflict. Besides that the conversion of agricultural land to housing will have a very broad impact.

\section{Methodology}

This type of research uses normative research, namely legal research that focuses on the study or review of laws and regulations, in accordance with specific legal scientific characteristics, with a study or legal review of applicable law (Positive law) which includes a legal layer of law consisting of dogmatic studies of law, legal theory, and legal philosophy. In connection with this type of research is normative legal research, where normative legal research has several types of approaches, namely regulatory approaches, case approaches, historical approaches, and conceptual approaches. ${ }^{1}$ As a normative study, the legal sources used in this study consist of sources of primary legal material and secondary legal material.

\section{Discussion}

\subsection{Analysis of Conflict Norms on the Transfer of Functions of Land Agricultural Functions and Agricultural Land Protection.}

In line with the provisions governing land stewardship, in the future a basic foundation for land stewardship is needed so as not to cause conflicts of interest within it. In addition to aspects that are the objectives of spatial planning, land stewardship must also refer to the basic policies regarding land that are in the LoGA and other laws related to land use. Considering that in the last few years due to Indonesia's population growth, besides requiring food supply, it also requires the provision of adequate boards. The provision of food and the second board are the same basic needs that require the provision of land. The construction of housing or settlements as an effort to provide boards that utilize agricultural land, this will result in the conversion of agricultural land whose impact will decrease agricultural land so that the supply of food will also decrease, while the provision of land for the construction of housing or settlements in order to provide

The board must also be fulfilled according to the pace of population development and growth and development. In connection with the above, the birth of Law No. 19 of 2013 concerning Protection and Empowerment of Farmers is very appropriate, because with this law the existence of farmers as users of agricultural land for the procurement and fulfillment of needs in the field of food will be protected. On the other hand the birth of Law No. 1 of 2011 concerning Housing and Settlement Areas is also appropriate for the providers of housing and settlement procurement, because the housing and settlement procurement program will be protected by the existence of the law. Likewise, Law Number 41 of 2009 concerning Sustainable Agricultural Land

However, if the two laws, namely Law Number 19 Year 2013 concerning Protection and Empowerment of Farmers, and Law Number 1 Year 2011 concerning Housing and Settlement Areas are met, then there will be a norm conflict. On the one hand with Law No. 19 of 2013 farmers as agricultural land users will be protected. While on the other hand with Law No. 1 of 2011 the organizers of housing and settlement procurement programs will be protected, while farmers as users of agricultural land will be threatened because there is always a reduction in agricultural land as a result of the provision of housing and settlements. This is where Law No. 41 of 2009 concerning Sustainable Agricultural Land actually functions to protect part of agricultural land, because according to this law agricultural land that is categorized as sustainable agricultural land is prohibited from being converted. As for what is allowed to be converted, agricultural land is in accordance with the Regional Spatial Plan (RTRW).

But in fact the opportunity for the occurrence of such norms can be suppressed because the government has legal authority to control and regulate the use of land resources, including the authority to control the conversion of agricultural land. Thus the expansion of the function of agricultural land lately is actually also inseparable from the inability of the government in controlling the conversion of land.

There are several regulations that explicitly or implicitly prohibit the conversion of agricultural land, even though it seems blunt. Some of the contributing factors are:

1. Weaknesses in the regulations themselves, especially those related to the issue of sanctions for violations and the accuracy of land objects that are prohibited from being converted;

2. Enforcement of the rule of law is currently very weak;

3. During the autonomous period the regulation issued in a centralized manner lacked legal force;

4. Dissemination of regulations that have not yet reached all levels of society, so that community control cannot take place effectively; and

5. The regulation rules seem to contradict the phenomenon of land use change that cannot be avoided as long as

\footnotetext{
${ }^{1}$ Peter Mahmud Masduki, Penelitian Hukum, cet. Ke 6, Kencana media Group, Jakarta, 2011, p. 93.
} 
economic growth is still a development goal.

\subsection{Analysis of Impacts That Occur Due to Transfer of Function of Agricultural Land for Housing.}

The impact of the conversion of agricultural land for housing is that the conversion of agricultural land into nonagricultural areas such as housing complexes, residential areas, industrial zones, trade areas, and other public facilities can cause negative economic, social and environmental impacts. For national food security the function of agricultural land to be non-agricultural is a serious threat, considering that the conversion of agricultural land to non-agriculture is difficult to avoid. While the impact on food is permanent, cumulative and progressive. Many regulations are issued by the government to control the conversion of agricultural land, but the juridical approach seems blunted due to various factors.

Increasing food security is one of the national development goals. In terms of production, the increase in food security is sought through increasing rice production, especially those produced from paddy fields. The consideration behind the policy is that rice is the staple food of the population which has the greatest contribution to the consumption of calories and protein. Such a pattern of food consumption causes scarcity of rice will greatly affect the adequacy of nutrition of the population. In addition, the productivity of farming in wetland rice is much higher than that of dryland rice farming. Such conditions cause the empowerment of paddy fields to produce rice will have a greater impact on food availability than empowering dry land.

As a result of increasing population and increasing per capita consumption stimulated by increases in household income, the need for rice / food continues to increase. To compensate for these needs, national rice production must increase adequately in order to maintain adequate food. "However, various studies reveal that the growth rate of rice production lately is actually as slow as it is"..$^{1}$ The slow rate of growth in rice production is caused by the slowing of the growth rate of productivity of rice farming due to the absence of technological breakthroughs that can significantly increase rice productivity. Whereas experience so far has shown that increasing rice productivity is a major factor for increasing national rice production.

In conditions where the productivity of rice farming is increasingly difficult to increase, an increase in the area of rice harvest is a forced effort to be made to increase national rice production. The increase in rice harvested area can be achieved through irrigation development which allows an increase in annual rice planting intensity and an increase in the area of rice fields by printing new rice fields. However, limited land resources and government budgets have made the two efforts increasingly difficult to realize. Lately, the area of rice fields has tended to decrease due to the conversion of agricultural land to non-agricultural land.

In a situation where rice production is increasingly difficult due to the increasing constraints on the expansion of paddy fields and the stagnation of farming technology, the conversion of agricultural land to non-agriculture will increase food problems.

Based on this, efforts to control the conversion of agricultural land to non-agriculture have an increasingly important role in supporting food security. Control efforts on the conversion of agricultural land are also needed to avoid various social, economic and environmental problems that can be stimulated by the conversion of agricultural land. However, efforts to control the conversion of agricultural land have seemed neglected. This is shown by the increasingly widespread consequences of the conversion of agricultural land . Many factors cause this condition, one of which is the attitude that sees the impact of the conversion of agricultural land as a small problem.

To better understand the problem of transferring agricultural land to non- agriculture, several related aspects need to be addressed. The intended aspects include:

1. Impact of that the function of agricultural land is economical, social and environmental;

2. Impact of the function of agricultural land is turned towards food security;

3. The nature of the impact of the conversion of agricultural land on food problems;

4. The pattern of use and the determinant of agricultural land which is used for use;

\subsubsection{Economic, Social and Environmental Impacts}

Agricultural land resources provide very broad benefits economically, socially and environmentally. Therefore the loss of agricultural land due to the conversion of agricultural land to non-agricultural use will have a negative impact on various aspects of development.

Broadly speaking, the benefits of agricultural land can be divided into two categories, namely: First, benefits value of use , $\mathrm{m}$ anfaat generated from exploitation or farming activities are carried out on agricultural land resources. Second, innate benefits. Included in this category of benefits are various benefits that are created by themselves even though they are not the purpose of the exploitation activities carried out by the land owners.

The first benefit category ( usage value ) can further be distinguished by direct benefits and indirect benefits. The direct benefits obtained from exploitation activities carried out on agricultural land can be of two types, namely:

${ }^{1}$ Irawan, B. Konversi Lahan sawah di jawa dan Dampaknya Terhadap Produksi Padi, Ekonomi Padi dan Beras Indonesia, Badan Litbang Pertanian, 2003, p. 295. 
a. In the form of output that can be marketed or marketed output, that is, various types of goods whose values can be measured empirically and expressed in output prices. Included in this type of benefit are various agricultural products produced from exploitation activities including leaves, straw, and wood which can be used as biomass. This type of benefit is individual, in the sense that the benefits obtained legally can only be enjoyed by landowners.

b. In the form of benefits whose value is not measured empirically or the price cannot be determined explicitly (unpriced benefit). This type of benefit can not only be enjoyed by land owners but can also be enjoyed by the public or communal. Examples are the availability of food, recreational facilities, a vehicle for the development of traditions and rural culture, and the availability of employment in rural areas which can further prevent urbanization which often creates various social problems in urban areas.

The indirect benefits of the existence of agricultural land are generally more related to environmental aspects. The existence of agricultural land from environmental aspects can provide benefits, namely: preventing flooding, controlling water balance, preventing erosion, reducing environmental pollution from household waste, and preventing air pollution from exhaust gases. All types of benefits are communal with a broader range of people, because the environmental problems they cause can be cross-regional.

\subsubsection{Impact on food security}

One of the effects of the conversion of agricultural land to non-agriculture which often gets the attention of the wider community is the disruption of food security which is one of the national development goals. Food security has a wide range of aspects and dimensions.

a. Conception of food security

The development of thinking about food security in Indonesia is inseparable from developments taking place at the world level. The concept of food security with a broader range of aspects has only been initiated at Pelita VII through Republic of Indonesia Law Number 7 of 1996 concerning food, where food security is defined as: "The conditions for fulfilling food for households are reflected and adequate food availability, both quantity and quality safe, even and affordable. The meaning of being affordable in this sense is that each individual has the ability to obtain food both physically (physical accessibility), while the availability of food in question can be in the form of food availability at the market or household level which can be obtained from self-produced products or bought on the market.

Based on the above definition, the scope of food security can be seen from three dimensions, namely:

- The dimensions of the scope of food security are national, regional and household spheres related to the quantity aspect of food availability;

- Dimensions of time and season related to aspects of stability of food availability over time;

- The socio-economic dimensions of the household are related to aspects of household accessibility to food, and aspects of food security.

Simatupang (1999), states "that the scope of food security starting from the national level to the individual level is basically a hierarchy with aspects of food security that are not always the same for every level of the hierarchy". ${ }^{1}$ Food security at the national, regional or local level does not always guarantee food security at the household level due to inequality in household income distribution. In this connection the problem of the smooth distribution of food also has an important role, so that available food can be accessed by all groups of poor and rich households.

b. Impact on several aspects of food security. As has been adjusted, the issue of food security has several aspects, namely aspects of quantity of food availability, aspects of stability of food availability, aspects of household accessibility to food, aspects of quality of food consumption, and aspects of food security. The transfer of functions of agricultural land to non-agriculture which is driven by various factors can have a negative impact on three aspects of food security. The first is the aspect of quantity of food availability, aspects of stability in food availability and aspects of accessibility of households to food. In summary, the mechanism of the effect of the conversion of agricultural land to non-agriculture on the three aspects of food security can be described as follows. 1. Aspect of Food Availability Quantity

The quantity of food availability can basically be fulfilled through domestic production or through imports. But for Indonesia which has a very large population, depending on the supply of food through imports will be at high risk due to the supply of world food that is quite thin, especially for manganese cereals. Besides that the provision of food through imports can drain foreign exchange reserves which are increasingly difficult to obtain. Under these conditions, for Indonesia can be said that there is no other option better than to produce food on their own through the utilization of the available resources.

Nationally, wetland resources have an important role in producing food. "Around 90 percent of national rice

\footnotetext{
${ }^{1}$ Simatupang P, Toward Sustainability Food Security : The Need For a New Paradigm, Paper Seminar On Agricultural Sector During The Turbulence Of Economic Crisis, Lesson and Future Directions, Caser Aard, Bogor, 1999.
} 
production is produced from paddy fields and the rest from dry land". ${ }^{1}$ Rice fields also have a large role in producing vegetables and polowijo such as corn, soybeans, and peanuts which are planted in the dry season. Therefore, the conversion of agricultural land to non-agriculture including housing will directly reduce the quantity of food availability due to reduced agricultural land that can be planted with rice and other food commodities. Not directly the function of agricultural land can also reduce the quantity of food availability due to the interruption of irrigation networks which in turn has an impact on decreasing farming productivity.

2. Food Security Stability According to Time.

The availability of food in quantity that meets national needs is a requirement for achieving food security. "However, this condition does not meet the requirements of adequacy if it is not followed by food distribution that is evenly distributed according to place and time so that it can be accessed by consumers at any time". 2

Ideally rice production can be produced every month to ensure the stability of the availability of staple food, so that every time consumers can meet their food needs. However, due to rice planting time which is strongly associated with rainfall patterns, rice harvesting can generally only be done in a particular month. In the dry season there is usually a decrease in rice production due to reduced yields from dry land and rainfed lowland so that consumers' accessibility to food has decreased. During the dry season most of the rice production is produced from irrigated paddy fields that have a more secure supply of irrigation water. Based on this, the conversion of agricultural land (irrigated rice fields) to non-agriculture can reduce the stability of food availability throughout the year due to reduced food production capacity that can be produced in the dry season.

3. Food Accessibility Aspects

Accessibility of households to food can be distinguished by physical accessibility and economic accessibility. Physical accessibility is strongly influenced by the food distribution system, while economic accessibility is influenced by the purchasing power of household food. While the purchasing of food for each household is very dependent on the price of food and the income of the household concerned. At the same level of food prices poor households or low income households have lower economic accessibility compared to rich households.

The poor household groups mentioned above are generally agricultural laborers who depend their livelihood on income from farming activities. If there is a shift in the function of agricultural land to non-agricultural land, especially irrigated land, which has relatively high absorption capacity, there will be a decline in the employment opportunities of farm workers which in turn will reduce the income of farm workers. Based on this, direct conversion of agricultural land to non-agricultural land will reduce the economic accessibility of farm workers to food, even though the poor are generally vulnerable to food insecurity. Besides that the food purchasing power of other community groups will also be reduced due to rising food prices stimulated by a decrease in food production caused by the conversion of agricultural land to non-agricultural.

\subsubsection{Nature of Impact on Food Problems}

The following description reveals some of the nature of the effects of the conversion of agricultural land to nonagriculture on food problems which are generally more detrimental than the impact of food problems caused by other factors.

a. Permanent Impacts

In the event of a pest attack, a decrease in food prices, droughts or floods of food problems caused can be said to be temporary, in the sense that these food problems only arise when the event occurs. But in the case of conversion of agricultural land to non-agriculture, the problem of food caused is permanent. That is, the food problem will still be felt in the long term, even though the conversion of agricultural land to non-agriculture has not happened again.

There are four factors that cause the impact of the conversion of agricultural land to non-agriculture on food problems cannot be restored quickly, namely:

First, the paddy fields that have been converted into non-agricultural functions are permanent, meaning that they will never turn back into paddy fields. In other words, "conversion of paddy fields to non-agricultural uses has an irreversible nature". This is because with the change of paddy fields into residential / residential areas, the value of land will increase by many times. This phenomenon is indicated by the comparison between the value of rental of paddy fields compared to the very large non-agricultural land rent.

Second, efforts to print new rice fields in the context of restoring food production in its original condition require a long term.

Third, land resources that can be used as rice fields are increasingly limited, especially in Java. Besides that, the government budget is also increasingly difficult, even though most of the rice field printing activities are supported by government funds. The limitations of land resources and government budgets, led to efforts to print paddy fields and rehabilitate irrigation networks to neutralize the chances of rice production being lost due to the

\footnotetext{
${ }^{1}$ Irawan B., B Winarso, I Sodikin, Gatoet, Analisis Faktor Penyebab Perlambatan Produksi Komoditas Pangan Utama, Pusat Litbang Sosial Ekonomi Pertanian, 2003. p. 325

${ }^{2}$ Simatupang P, Anatomi Masalah Produksi Beras Nasional Dan Upaya Mengatasinya, Pusat Litbang Sosial Ekonomi Pertanian, Bogor, 2000, p. $9-10$
} 
conversion of agricultural land to non-agricultural land that is not easily realized.

Fourth, to be able to anticipate production opportunities lost due to the conversion of agricultural land, one way that can be taken is to increase the productivity of rice farming. But due to the stagnation of technological innovations in recent years, these efforts are increasingly difficult to realize.

b. Cumulative Impact

The reduction in the area of permanent rice fields causes food problems caused by the conversion of agricultural land for a certain period of time to be cumulative. The impact of the conversion function of agricultural land is that, if during that period there was no increase in farming productivity and rice crop intensity. Then the annual rice production depends entirely on the area of rice fields available.

Before the occurrence of the conversion of agricultural land to non-agricultural rice production is as large as the quantity of rice needed, in other words it is not necessary to import rice to meet the needs of the land. If in the coming years there will be a change in the function of agricultural land, the rice production achieved will decrease. At the production level, the government must import rice to meet the rice's needs. The decrease in the quantity of rice production is actually the impact of the transfer of land fung in the intertwined year (TS +1$)$.

If in the following year there was no more land conversion, then rice imports would still be carried out to meet the need for rice. But if the following year $(\mathrm{TS}+2)$ takes place again the conversion of agricultural land will result in a decrease in the second quantity of rice production. This will happen continuously, which in turn will reduce the quantity of rice production to meet food demand.

c. Progressive Impact

In line with changes in the structure of the economy which is the development of a country or region, the need for land for non-agricultural activities will increase from year to year. These trends led to conversion of agricultural land is difficult to avoid, in other words every year definitely going over the land.

The area of conversion of agricultural land will increase every year because land conversion is generally contagious. In other words, once the function of the agricultural land takes place in a location, the area of land that is converted into that location will be even greater due to the transfer of follow-up functions that occur in the surrounding area.

Symptoms of transmission of land use can be caused by two interrelated factors, namely: In line with the construction of residential areas or industrial estates in a location experiencing conversion of agricultural land, the accessibility in the relevant location is getting better due to the development of transportation facilities and infrastructure, so that the price of land in the surrounding area has increased. Increasing land prices further encouraged other farmers in the surrounding areas to sell their land. Buyers of the land are usually not local residents so that the land will be formed for shunts which are generally vulnerable to the land conversion process.

Meanwhile, due to increased farming technology, the productivity of rice farming per year will increase. This tendency causes the opportunity for lost rice production for each rice per year to increase. This tendency causes the opportunity for lost rice production for every hectare of land which will increase function from year to year. This means that even though the area of and converted per year for a certain period is fixed, the opportunity for rice production lost due to the conversion of land will be even greater. In other words, food problems are caused by every hectare of land being converted bigger from year to year (progressive).

\subsubsection{Patterns of Use and Determinants of Factors}

The shift in function of agricultural land to non-agriculture basically occurs due to competition in land use between the agricultural sector and the non- agricultural sector. While competition in land use arises due to the existence of three economic and social phenomena, namely:

a. Limited land resources;

b. Population growth;

c. Economic growth.

In each area, the available land area is relatively fixed or limited so that population growth will increase the scarcity of land that can be allocated for agricultural and non-agricultural activities. Meanwhile economic growth tends to encourage demand for land for non-agricultural activities at a higher rate than demand for land for agricultural activities because of consideration of non-agricultural products that are more elastic to income. Increasing the scarcity of land due to population growth, coupled with the increase in demand for land that is relatively high for non-agricultural activities due to economic growth eventually led to the conversion of agricultural agricultural land.

The three phenomena mentioned above are difficult to prevent, especially in developing countries which generally have a relatively high rate of population growth and economic growth . Economic development will require land to be used for the construction of transportation facilities and other public facilities and land requirements for non-agricultural activities such as industrial estates and trade zones. Whereas population growth will stimulate an increase in land requirements for housing and settlement development.

In developing countries (Indonesia) that experience high economic growth, the economic structure tends to shift from the one originally based on the agricultural sector to the non-agricultural sector. Changes in economic 
structure that causes the demand for land for non-agricultural activities increased rapidly, thus stimulating the conversion of farmland to non-agricultural allocated for the development of industrial estates and commercial area. The development of the two regions subsequently attracted population migration to the area, resulting in the transfer of follow-up functions aimed at the construction of residential and residential complexes.

From an economic point of view, the conversion of agricultural land to non-agriculture can be caused by the pull of demand for land for non-agricultural activities and the encouragement of agricultural land supply by farmers who own land. The behavior of demand and supply of land is inseparable from economic, social and public development policies so that the phenomenon of land use change is inseparable from the policies pursued by the government. For example, the subsidy policy for the construction of low-cost housing will increase the demand for land for housing development so that it can stimulate land use conversion. Whereas policies in the social sector that are unable to reduce the rate of population growth can stimulate the conversion of land due to rising housing needs. Likewise, the development policy of transportation facilities and other public facilities that are not well planned, can also lead to the conversion of paddy fields.

Land supply and demand behavior as mentioned above will basically affect the chance of land conversion. Opportunities for land conversion are greater in paddy fields than dry land due to three factors:

1. Development of non-agricultural activities such as housing, shops, offices, and industrial estates is easier to do in wetland areas that are flatter than dry land;

2. As a result of past development focused on efforts to increase rice production, more economic infrastructure is available in rice fields than in dry land areas;

3. Rice fields in general are closer to consumer areas or urban areas that are relatively densely populated compared to dry land areas, most of which are in hilly and mountainous regions.

\section{Conclusion}

The occurrence of conflict of norms to setting of the function of agricultural land and protection of agricultural land, as well as widespread over the function of agricultural land end of is actually inseparable from the inability of the government in controlling land conversion. There are several regulations that explicitly or implicitly prohibit the conversion of agricultural land, even though it seems blunt. Some of the contributing factors are:

1. Weaknesses in the regulations themselves, especially those related to the issue of sanctions for violations and the accuracy of land objects that are prohibited from being converted;

2. Enforcement of the rule of law is currently very weak;

3. During the autonomous period the regulation issued in a centralized manner lacked legal force;

4. Dissemination of regulations that have not reached all levels of society, so that community control cannot take place effectively; and

5. The regulation rules seem to contradict the phenomenon of land use change that cannot be avoided as long as economic growth is still a development goal.

A function of agricultural land to be non-agricultural, such as for housing complexes, settlements, industrial estates, trade areas, and other public facilities can cause negative economic, social and environmental impacts. For national food security the function of agricultural land to be non-agricultural is a serious threat, considering that the conversion of agricultural land to non-agriculture is difficult to avoid. While the impact on food is permanent, cumulative and progressive. Many regulations are issued by the government to control the conversion of agricultural land, but the juridical approach seems blunted due to various factors.

\section{References}

Irawan, B. Konversi Lahan sawah di jawa dan Dampaknya Terhadap Produksi Padi, Ekonomi Padi dan Beras Indonesia, Badan Litbang Pertanian, 2003.

., B Winarso, I Sodikin, Gatoet, Analisis Faktor Penyebab Perlambatan Produksi Komoditas Pangan Utama, Pusat Litbang Sosial Ekonomi Pertanian, 2003.

Simatupang P, Toward Sustainability Food Securit: The Need For a New Paradigm, Paper Seminar On Agricultural Sector During The Turbulence Of Economic Crisis, Lesson and Future Directions, Caser Aard, Bogor, 1999.

, Anatomi Masalah Produksi Beras Nasional Dan Upaya Mengatasinya, Pusat Litbang Sosial Ekonomi Pertanian, Bogor, 2000. 